\title{
Amphetamine, mazindol, and fencamfamin in narcolepsy
}

\author{
J SHINDLER, M SCHACHTER, S BRINCAT, J D PARKES
}

\begin{abstract}
Twenty patients with the narcoleptic syndrome were treated separately with dexamphetamine sulphate tablets 10 and $30 \mathrm{mg}$, Dexedrine Spansules $10 \mathrm{mg}$, mazindol $4 \mathrm{mg}$, and fencamfamin hydrochloride $60 \mathrm{mg}$ daily. Each drug was given for four weeks and the effects compared. In these dosages the reported frequency of attacks of narcolepsy was roughly halved with each treatment, dexamphetamine $30 \mathrm{mg}$ daily being only slightly more potent than $10 \mathrm{mg}$. The subjective effects of Dexedrine tablets and Spansules could not be distinguished by most patients. Effects on mood, alertness, and sympathomimetic side effects were largely inseparable with all these drugs, but a decrease in appetite was not reported by patients with narcolepsy.
\end{abstract}

\section{Introduction}

There are an estimated 20000 people with narcolepsy in Britain and 100000 in the United States. ${ }^{1}$ Most of them require lifelong treatment with central stimulant drugs to increase alertness and reduce daytime drowsiness. At least 20 central stimulant, mood raising, or appetitite suppressant drugs are available world wide, and as many as 10 are used in Britain (caffeine, ephedrine, amphetamine, pemoline, fencamfamin, prolintane, diethylpropion, phentermine, mazindol, and fenfluramine). All of these drugs reduce appetitite and alter (usually increase) alertness, but all also have sympathomimetic effects. In most instances clinical use has been determined by the pattern of drug development, not by any definite selectivity of action, although fenflura-

\footnotetext{
University Department of Neurology, King's College Hospital and Institute of Psychiatry, London SE5

J SHINDLER, MB, BS, research registrar

M SCHACHTER, MB, MRCP, research registrar

$S$ BRINCAT, MRCP, senior house officer

J D PARKES, MD, FRCP, reader in neurology

Correspondence to: Dr J D Parkes, Department of Neurology, King's College Hospital, London SE5 9RS.
}

mine has only minor alerting effects. ${ }^{2}$ Amphetamine abuse, either to increase performance in sportsmen or cause euphoria, has led to legal restrictions on the manufacture, distribution, and prescription of this class of drugs, and in some countriesfor example, Spain-no drug of proved efficacy is available for narcolepsy, or supplies are severely restricted.

The central stimulant drugs of choice in the treatment of narcolepsy have not been determined, nor indeed do we know the required mechanism of action; patients with narcolepsy have frequent attacks of sleep during the day and sleep onset rapid eye movement (REM) periods-hence is the aim to reduce REM sleep or increase alertness, or both ? Also the effective dose ranges of central stimulant drugs in narcolepsy have not been defined: many patients take high dosages-for example, dexamphetamine sulphate $60-100 \mathrm{mg}$ daily-without obvious greater benefit than from lower doses, although often with obvious toxic symptoms.

Ephedrine has been used as a stimulant for at least 5000 years but causes fairly frequent sweating, anorexia, and tachycardia. ${ }^{3}$ Amphetamine was introduced after the encephalitis lethargica era as a more effective stimulant, with less sympathomimetic activity than ephedrine, ${ }^{4}$ and some patients have now taken D-, L-, or DL-amphetamine, often in delayed release formulation, with satisfactory results for almost half a century. The delayed release formulation of amphetamine (Dexedrine Spansule), however, was withdrawn from the British market in 1978. Methylphenidate was considered by Daly and Yoss to be the most satisfactory drug available in the $1950 \mathrm{~s},{ }^{5}$ but no direct comparison has ever been done, and methylphenidate was withdrawn in Britain in 1984 to near universal complaint by patients (methylphenidate is, however, still available on a named patient basis for those established on the drug). Mazindol was first used for narcolepsy in $1979 .{ }^{6}$ Since then we have treated 47 patients with mazindol $2-12 \mathrm{mg}$ daily for up to five years with sustained effect and no serious adverse reactions, although tolerance, anorexia, or inadequate control of narcolepsy limited treatment in a further eight subjects. In the doses investigated, mazindol is not as potent a stimulant as amphetamine.

We have compared the effects of amphetamine in narcolepsy with mazindol and fencamfamin, two drugs developed primarily as appetite suppressants or pscyhostimulants, not to increase awareness, and which have little or no sympathomimetic activity in animals. Mazindol is a non-phenylethylamine derivative 
which, like amphetamine, prevents REM sleep but does not increase alertness when given acutely in low dosage to normal volunteers." Fencamfamin, like amphetamine, has a phenylethylamine structure and reduces REM sleep and prevents fatigue in subjects deprived of sleep.

\section{Patients and methods}

We studied 20 patients ( 11 women) attending the King's College Hospital sleep disorders clinic for the narcoleptic syndrome. All had narcolepsy, 12 with cataplexy and eight with sleep paralysis. Patients were aged 28-65 years (mean 49), and the duration of their narcolepsy was 7-45 years (mean 25) and of cataplexy or sleep paralysis 5-40 years (mean 21). No patient had cardiovascular, respiratory, or hepatic impairment. The study was approved by the hospital's ethical committee, and informed consent was obtained in every case.

\section{ASSESSMENT OF SLEEP, ALERTNESS, AND MOOD}

The severity of narcolepsy and the effect of treatment were evaluated (a) by numerical and linear self rating scales for sleep, alertness, mood, and appetite derived from the scale developed by the MRC Applied Psychology Unit, Cambridge, to measure mood and arousal (see Appendix $)^{9}$ and $(b)$ by score systems devised to evaluate drugs in narcolepsy. ${ }^{10}$ The scales were completed at two week intervals, on the same working day, and scores for sleep, mood, and other variables were determined over a four week period with each drug investigated. Patients also completed a questionnaire on adverse reactions.

Radial pulse, supine and erect blood pressure, and weight were measured before and after four weeks of each treatment.

\section{DRUGS AND FORMULATIONS}

Phase 1-Low dose treatment was give with (a) dexamphetamine sulphate as Dexedrine Spansules; $(b)$ dexamphetamine sulphate as Dexedrine tablets; and (c) mazindol (Teronac).

Phase 2-High dose treatment was given with $(d)$ dexamphetamine sulphate as Dexedrine tablets and (e) fencamfamin hydrochloride (as pure substance, not Reactivan).

Seven patients continued with a stable dose of clomipramine 25-100 mg daily for cataplexy throughout.

\section{STUDY DESIGN}

The trial began with a two week period free of drugs. An initial assessment of the frequency of narcolepsy and cataplexy was then made and scores for sleep, alertness, mood, and appetite determined.

\section{Phase 1}

Phase 1 (low dose treatment) lasted 12 weeks. It consisted of three sequential four week periods, in each of which patients took a separate regimen containing one active and two placebo preparations.

In one period the regimen was: Dexedrine Spansules $10 \mathrm{mg}$ at $8 \mathrm{am}$; matched placebo for Dexedrine tablets $5 \mathrm{mg}$ at $8 \mathrm{am}, 5 \mathrm{mg}$ at 12 noon; matched placebo for mazindol $2 \mathrm{mg}$ at $8 \mathrm{am}, 2 \mathrm{mg}$ at 12 noon.

In a second period the regimen was: matched placebo for Dexedrine Spansules $10 \mathrm{mg}$ at $8 \mathrm{am}$; Dexedrine tablets $5 \mathrm{mg}$ at 8 am, $5 \mathrm{mg}$ at 12 noon; matched placebo for mazindol $2 \mathrm{mg}$ at $8 \mathrm{am}, 2 \mathrm{mg}$ at 12 noon.

In a third period the regimen was: matched placebo for Dexedrine Spansules $10 \mathrm{mg}$ at $8 \mathrm{am}$; matched placebo for Dexedrine tablets $5 \mathrm{mg}$ at $8 \mathrm{am}, 5 \mathrm{mg}$ at 12 noon; mazindol $2 \mathrm{mg}$ at $8 \mathrm{am}, 2 \mathrm{mg}$ at 12 noon.

\section{Phase 2}

Phase 2 (high dose treatment) lasted eight weeks and comprised two sequential four week periods of treatment.
In one period the regimen was: Dexedrine tablets $10 \mathrm{mg}$ at $8 \mathrm{am}, 10 \mathrm{mg}$ at 12 noon, $10 \mathrm{mg}$ at $2 \mathrm{pm}$; matched placebo for fencamfamin $20 \mathrm{mg}$ at $8 \mathrm{am}, 20 \mathrm{mg}$ at 12 noon, $20 \mathrm{mg}$ at $2 \mathrm{pm}$.

In the other period the regimen was: matched placebo for Dexedrine tablets $10 \mathrm{mg}$ at $8 \mathrm{am}, 10 \mathrm{mg}$ at 12 noon, $10 \mathrm{mg}$ at $2 \mathrm{pm}$; fencamfamin $20 \mathrm{mg}$ at $8 \mathrm{am}, 20 \mathrm{mg}$ at 12 noon, $20 \mathrm{mg}$ at $2 \mathrm{pm}$.

\section{Other details}

Phase 1 preceded phase 2, patients being supplied with individually numbered, dated, and labelled containers to help compliance. The order of taking the active drug in each phase was random, and the trial was double blind.

All subjects completed phases 1 and 2 , but five kept inadequate records during phase 1 and are therefore included only in the analysis of adverse reactions in that part of the study.

At the end of the trial, periods of active medication were identified and the results of each treatment compared with the initial no treatment assessment. The frequency of narcolepsy, cataplexy, and sleep paralysis and subjective mood scores (mean sum of two and four weeks of drug assessments) were compared with those before treatment.

Student's $t$ test was used to compare differences in frequency of attacks, and the Wilcoxon matched pair signed rank test was used to assess differences in subjective rating scales.

\section{Results}

PHASE 1

Dexamphetamine tablets $10 \mathrm{mg}$ ( $5 \mathrm{mg}$ at $8 \mathrm{am}, 5 \mathrm{mg}$ at 12 noon), dexamphetamine Spansules $10 \mathrm{mg}$ (single dose at $8 \mathrm{am}$ ), and mazindol $4 \mathrm{mg}$ ( $2 \mathrm{mg}$ at $8 \mathrm{am}, 2 \mathrm{mg}$ at 12 noon) all reduced the reported number of sleep attacks during the day as compared with the no treatment period, the frequency of attacks being roughly halved with each drug. No treatment altered the reported duration of nocturnal sleep, the number of awakenings at night, or the frequency of waking attacks of cataplexy. The frequency of sleep paralysis was reduced during treatment with each drug (table I).

Subjective rating scales for alertness (drowsy-alert, dreamyattentive), motor coordination (clumsy-well coordinated), energy (lethargic-energetic), and mood (sad-happy) were improved to a comparable extent by each of the three preparations (table I). Fourteen other scales (of a total of 19) showed no consistent or significant alteration in other variables of mood, alertness, appetite, or hunger.

Adverse reactions attributed to dexamphetamine or mazindol were similar to but less frequent than similar complaints described before the trial in drug free patients (table II). Six patients reported an increase in appetitite at the end of the initial two week drug withdrawal period, but there was no subsequent evidence that any drug suppressed appetite in patients with narcolepsy.

Patient preferences for treatment period at the end of phase 1 were given as dexamphetamine tablets, four patients; dexamphetamine Spansules, two (only two of 15 patients could distinguish correctly the dexamphetamine Spansule period from the period of taking dexamphetamine tablets); and mazindol, six patients. Three subjects gave no preference.

PHASE 2

Dexamphetamine $30 \mathrm{mg}$ daily (as tablets) was only slightly more effective than dexamphetamine $10 \mathrm{mg}$ daily in reducing the frequency of sleep attacks during the day (mean number of attacks per day 2.7 with $10 \mathrm{mg}, 2 \cdot 2$ with $30 \mathrm{mg}$ ).

Dexamphetamine $30 \mathrm{mg}$ and fencamfamin $60 \mathrm{mg}$ daily were equipotent in their alerting effect, with a comparable number and duration (mean 40 minutes and 50 minutes respectively) of sleep attacks with each drug. Although fencamfamin has a slightly longer elimination half life than amphetamine, the number of reported attacks of daytime drowsiness was similar at the end of two and four weeks of treatment. After the first 48 hours neither dexamphetamine $30 \mathrm{mg}$ nor fencamfamin $60 \mathrm{mg}$ altered the reported total duration of night sleep or the number of nocturnal arousals. The frequency of cataplexy (12 patients) and sleep paralysis (eight) was slightly greater with fencamfamin than dexamphetamine, although mood and all the 18 other subjective self rating scores measured were similar with both treatments. 
TABLE I-Effects of dexamphetamine, mazindol, and fencamfamin in narcolepsy (4 weeks' treatment with each drug). Values are means (1 SEM given in parentheses)

\begin{tabular}{|c|c|c|c|c|c|c|}
\hline & \multirow[b]{2}{*}{ No treatment } & \multicolumn{3}{|c|}{ Phase 1} & \multicolumn{2}{|c|}{ Phase 2} \\
\hline & & $\begin{array}{c}\text { Dexamphetamine } \\
\text { (as tablets) } 5 \mathrm{mg} \\
8 \mathrm{am}, 5 \mathrm{mg} 12 \mathrm{noon}\end{array}$ & $\begin{array}{l}\text { Dexamphetamine } \\
\text { (as Spansules) } 10 \mathrm{mg} \\
8 \mathrm{am}\end{array}$ & $\begin{array}{l}\text { Mazindol } 2 \mathrm{mg} 8 \mathrm{am}, \\
2 \mathrm{mg} 12 \text { noon }\end{array}$ & $\begin{array}{l}\text { Dexamphetamine } \\
\text { (as tablets) } 10 \mathrm{mg} 8 \\
\text { am, } 10 \mathrm{mg} 12 \mathrm{noon}, \\
10 \mathrm{mg} 2 \mathrm{pm}\end{array}$ & $\begin{array}{c}\text { Fencamfamin } 20 \mathrm{mg} \\
8 \mathrm{am}, 20 \mathrm{mg} 12 \mathrm{noon}, \\
20 \mathrm{mg} 2 \mathrm{pm}\end{array}$ \\
\hline No of attacks of narcolepsy day & $4 \cdot 4(0 \cdot 6)$ & $2.7(0.7)$ & $2 \cdot 4(0 \cdot 7)^{*}$ & $2 \cdot 1(0.5)$ & $2 \cdot 2(0 \cdot 3) * *$ & $2.8(0.5)^{*}$ \\
\hline No of attacks of cataplexy day & $2 \cdot 1(0 \cdot 6)$ & $2 \cdot 0(0 \cdot 6)$ & $2 \cdot 1(0 \cdot 8)$ & $1.2(0.4)$ & $1.4(0.9)$ & $2.5(1.0)$ \\
\hline No of attacks of sleep paralysis day & $1 \cdot 1(0 \cdot 3)$ & $0.7(0.2)$ & $0.5(0.2)$ & $0.2(0 \cdot 1) * *$ & $1.6(1.0)$ & $3 \cdot 6(1 \cdot 0)^{*}$ \\
\hline \multicolumn{7}{|l|}{ Subjective rating scales $0-100$ : } \\
\hline $\begin{array}{l}\text { Drowsy-alert } \\
\text { Dreamy-attentive } \\
\text { Clumsy-well coordinated } \\
\text { Lethargic-energetic } \\
\text { Sad-h?ppy }\end{array}$ & $\begin{array}{l}24 \cdot 2(4 \cdot 8) \\
35 \cdot 6(4 \cdot 8) \\
39 \cdot 2(6 \cdot 1) \\
20 \cdot 8(3 \cdot 9) \\
25 \cdot 3(5 \cdot 3)\end{array}$ & $\begin{array}{l}34.9(5.9) \\
48.3(5.3) \\
43.5(5.1) \\
30 \cdot 8(5.1) \\
40.5(5.9)\end{array}$ & $\begin{array}{l}40.4(6 \cdot 0)^{*} \\
43.4(5 \cdot 7) \\
48 \cdot 2(6 \cdot 3) \\
34 \cdot 8(5 \cdot 6)^{*} \\
41.3(5 \cdot 7)^{*}\end{array}$ & $\begin{array}{l}47 \cdot 3(5 \cdot 1)^{* * *} \\
45 \cdot 3(5 \cdot 2) \\
49 \cdot 5(5 \cdot 9) \\
38 \cdot 8(5 \cdot 9)^{*} \\
42 \cdot 0(6 \cdot 0)^{*}\end{array}$ & $\begin{array}{l}56 \cdot 8(4 \cdot 5)^{* * * *} \\
56 \cdot 1(5 \cdot 0)^{* * *} \\
51 \cdot 1(5 \cdot 0) \\
50 \cdot 2(5 \cdot 0)^{* * *} \\
51 \cdot 4(4 \cdot 6)^{* * *}\end{array}$ & $\begin{array}{l}57 \cdot 3(4 \cdot 7)^{* * * *} \\
48 \cdot 1(3 \cdot 0)^{*} \\
49 \cdot 3(5 \cdot 6) \\
50 \cdot 6(5 \cdot 4)^{* * *} \\
52 \cdot 4(3 \cdot 6)^{* * *}\end{array}$ \\
\hline
\end{tabular}

Compared with no treatment: ${ }^{*} p<0.05 ; * * p<0.01 ; * * * p<0.001$

TABLE II-Incidence of side effects of dexamphetamine, mazindol, and fencamfamin (4 weeks' treatment with each drug). Figures are numbers of patients reporting each side effect (data from 20 subjects)

\begin{tabular}{|c|c|c|c|c|c|c|}
\hline & \multirow[b]{2}{*}{ No treatment } & \multicolumn{3}{|c|}{ Phase 1} & \multicolumn{2}{|c|}{ Phase 2} \\
\hline & & $\begin{array}{l}\text { Dexamphetamine (as } \\
\text { Dexedrine tablets) } 5 \mathrm{mg} \\
8 \mathrm{am}, 5 \mathrm{mg} 12 \mathrm{noon}\end{array}$ & $\begin{array}{l}\text { Dexamphetamine (as } \\
\text { Spansules) } 10 \mathrm{mg} 8 \mathrm{am}\end{array}$ & $\begin{array}{l}\text { Mazindol } 2 \mathrm{mg} 8 \mathrm{am}, \\
2 \mathrm{mg} 12 \text { noon }\end{array}$ & $\begin{array}{c}\text { Dexamphetamine (as } \\
\text { tablets) } 10 \mathrm{mg} 8 \mathrm{am}, \\
10 \mathrm{mg} 12 \mathrm{noon}, \\
10 \mathrm{mg} 2 \mathrm{pm}\end{array}$ & $\begin{array}{c}\text { Fencamfamin } 20 \mathrm{mg} \\
8 \mathrm{am}, 20 \mathrm{mg} 12 \mathrm{noon}, \\
20 \mathrm{mg} 2 \mathrm{pm}\end{array}$ \\
\hline $\begin{array}{l}\text { Sweaty } \\
\text { Palpitations } \\
\text { On edge }\end{array}$ & $\begin{array}{l}6 \\
2 \\
7\end{array}$ & $\begin{array}{l}5 \\
1 \\
6\end{array}$ & $\begin{array}{l}5 \\
1 \\
7\end{array}$ & $\begin{array}{l}6 \\
2 \\
7\end{array}$ & $\begin{array}{l}3 \\
2 \\
4\end{array}$ & $\begin{array}{l}3 \\
1 \\
3\end{array}$ \\
\hline
\end{tabular}

Insomnia was reported during the initial 48 hours, but not subsequently, in one patient beginning fencamfamin. In two subjects taking dexamphetamine $30 \mathrm{mg}$ daily a dose reduction (to 10 and $20 \mathrm{mg}$ daily) was necessary because of anxiety and headache in one patient and continued insomnia in the other. Both subjects tolerated fencamfamin $60 \mathrm{mg}$ daily without similar adverse effects.

Three patients described the alerting effect of both dexamphetamine $30 \mathrm{mg}$ and fencamfamin $60 \mathrm{mg}$ daily as less than that of higher doses of dexamphetamine (45 and $70 \mathrm{mg}$ respectively) or mazindol (4 mg) taken before the trial started. Patient preferences for treatment period were give as dexamphetamine, seven subjects; and fencamfamin, nine. Four subjects gave no preference.

There was no significant change in erect systolic and diastolic blood pressure, pulse rate, weight, or subjective assessment of appetite between treatment periods or compared with before the trial.

\section{Discussion}

The action of any central stimulant drug varies with the subject and the setting-for example, occasionally amphetamine may cause sedation, not alertness. Fat people, and patients with narcolepsy, may show different responses to these drugs, which have little or no effect on appetite or weight when taken in the long term by narcoleptics to prevent daytime drowsiness. The comparative value of these drugs in narcolepsy requires their subjective evaluation in everyday life, not their objective evaluation in normal volunteers, obese subjects, or patients with narcolepsy in the sleep laboratory. Under real life circumstances no single stimulant drug can be determined as a "best" treatment, and there are pronounced individual differences in preference. Very roughly, equipotent doses in narcolepsy are dexamphetamine $10 \mathrm{mg}$, fencamfamin $20 \mathrm{mg}$, and mazindol $4 \mathrm{mg}$. Differences in formulation do not appear to be important: although dexamphetamine delayed release formulation (Dexedrine Spansules) resulted in an increase in flicker fusion frequency for a slightly longer period than the same dose gives in tablet form $(6.0$ as compared with 4.5 hours in six subjects in this trial), the effectiveness of these two preparations in narcolepsy cannot readily be distinguished by patients. Also, pharmacokinetic differences among the different stimulants may not be of great practical importance in the treatment of narcolepsy. Although fencamfamin and mazindol have longer plasma elimination half lives at normal urinary $\mathrm{pH}$ than does dexamphetamine (around 12,
30 , and six hours respectively), ${ }^{11-13}$ the stimulant effect of a single dose of any of these drugs, both at the start and after four weeks of treatment, is comparatively short-around four to six hours.

Tolerance may lead to the use of very high doses of amphetamines-for example, over $100 \mathrm{mg}$ daily-but this may not be so great a problem with either fencamfamin or mazindol. Also, misuse of these compounds may be less than with amphetamine, although any effective central stimulant drug that causes euphoria presents a potential hazard. There are only a few reports of tolerance or addiction to mazindol and/or fencamfamin. ${ }^{14}$

Amphetamine, fencamfamin, and mazindol all raise mood. There were no specific or different effects of the drugs on mood and on alertness. Moruzzi considered that high degrees of alertness were inseparable from elevation of mood, extreme levels of alertness culminating in rage and mania..$^{15}$ Amphetamine is a fairly effective mood raising drug, and the advice of the British National Formulary not to use amphetamine as an antidepressant may be founded more on the danger of abuse than on any definite lack of therapeutic effect. ${ }^{16}$ Sympathomimetic side effectspalpitations, sweating, and occasional irritability-largely parallel the increase in alertness and mood, though are possibly less severe with mazindol and fencamfamin than with amphetamine. All reduce REM sleep, although in the case of amphetamine, tolerance to this develops over a few months, with normal REM sleep time in hyperkinetic children receiving long term amphetamine treatment. ${ }^{17}$

In the absence of evidence of drug superiority, greater clinical benefit, or fewer side effects we recommend that at present two or three alternative preparations should be available for the treatment of narcolepsy. Low dose treatment is almost as effective as high dose. The conventional idea that central stimulant drugs have different properties from anorectic drugs may be largely incorrect, the drug action depending on the population investigated as well as the expected effect.

We acknowledge the support of Sandoz, Warner, Smith Kline and French, and Merck; and Dr G Kennedy, Dr A C Flind, Mr M Whitford, and Dr J Weber. Fencamfamin was supplied as pure substance (not as Reactivan, which contains additional vitamins) by Messrs E Merck, Darmstadt, FRG. We are grateful to Mrs L Gibson for secretarial help. 


\section{Appendix}

The 19 subjective rating scales used were: mentally slowquickwitted; withdrawn-sociable; incompetent-proficient; feeble-strong; tense-relaxed; self centred-outward going; bored-interested; calm-excited; antagonistic-friendly; troubledtranquil; dreamy-attentive; muzzy-clearheaded; low-high; discontented-contented; drowsy-alert; depressed-elated; clumsy-well coordinated; lethargic-energetic; sad-happy.

\section{References}

1 Dement W, Zarcone V, Varner V, et al. The prevalence of narcolepsy. Sleep Research $1972 ; 1: 148$

2 Holmstrand J, Jonsson J. Subjective effects of two anorexigenic agents-fenflura-

3 Janota $O$ Symptomatische Behandlung der pathologischen Schlafsucht, besonders der Narkolepsie. Medizinische Klinik 1931;27:278-81.

4 Prinzmetal M, Bloomberg W. The use of Benzedrine for the treatment of narcolepsy. FAMA 1935;105:2051-4

5 Daly DD, Yoss RE. The treatment of narcolepsy with methyl phenylpiperidy- lacetate; a preliminary report. Proceedings of the Staff Meeting of the Mayo 6 Parkes JD S,31:620-5. Scand $1979 ; 60: 250-4$.

Hedges A. AN448 on critical flicker fusion and heart rate in man. $S$ Afr Med $1972 ; 46: 139$.

8 Holliday AR, Devery WJ. Effects of drugs on the performance of a task by fatigued subjects. Clin Pharmacol Ther 1962;3:5-15.

9 Munday B, Kendall MJ, Mitchard M, Betts TA. A single dose study of trazodone with an assessment of its effect on mood and arousal. Br f Clin Pharmacol 1975 ; 2:19-24

10 Schachter M, Parkes JD. Fluroxamine and clomipramine in the treatment of cataplexy. F Neurol Neurosurg Psychiatry 1980;43:171-4.

11 Beckett $\mathrm{AH}$, Rowland $\mathrm{M}$, Turner $\mathrm{P}$. Influence of urinary $\mathrm{pH}$ on excretion of

12 Gogerty JH, Penberthy C, Iorio IC, Trapold JH. Pharmacological analysis of a new anorectic substance: 5-hydroxy-5-(4'chlorophenyl)-2, 3-dihydro-5Himidazo-(2,1-a) isonidole (mazindol). Archives Internationales de Pharmacody namie 1975;214:285-307.

13 Vree TB, Van Rossum JM. Suppression of renal excretion of fencamfamin in man. Eur $\mathcal{F}$ Pharmacol 1969; 7:227-30

14 Craddock D. Anorectic drugs. Drugs 1976;11:378-93.

Moruzzi G. The sleep-waking cycle. Ergebnisse der Physiologie, biologischen Chemie und experimentellen Pharmakologie 1972;64:1-165.

(itary. No 7. London: British Medical Association, Pharmaceutical Society of Great Britain, 1984:152. Medical Association, Pharmaceutical Society of Great Britain, 1984:152.
Sroufe LA, Stewart MA. Treating problem children with stimulant drugs.
N Engl F Med 1973;289:407-13.

(Accepted 12 December 1984)
"Whatever men may be in other things, they are not 'mostly fools,", observes the Lettsomian Lecturer of 1885, "in regard to the plan of their meals." A plain dinner ordinarily consists of soup, fish, joint, pudding, bread and cheese, and dessert; and there is a philosophic fitness in the order in which these courses are arranged, and in the principal comestibles whereof they are composed. A stomach which has at all recently performed the function of digesting a fairly substantial meal, providing by its glandular apparatus a sufficient quantity of gastric juice of good quality, is not in a condition to undertake a similar duty unless it be itself first stimulated and strengthened for the task. Peptogens must be supplied to induce and enable the stomach to secrete a proper amount of pepsine. Soup made from meat-extractives, and bread which provides dextrin, afford the nourishment requisite for the gastric organ, and enable it to do its work vigorously. In countries where the meat is generally tough, and not easily soluble, as in France, soup at the commencement of a dinner is a gastronomic necessity, and the people resort to it instinctively, without knowing why. In England, where meat is commonly tender and juicy, soup is less urgently needed, but is, nevertheless, always desirable. Its use is to be enjoined on the obvious principle and policy, of feeding the steed before we ask it to bear a burden. Then comes the fish, not superlatively nutritious in itself, as some food-economists seem to have assumed from its effects, but particularly easy of digestion, or, more accurately speaking, of solution. As Dr. Brunton points out, it is the ready solubility of food that constitutes the first and main feature in the quality of digestibility, and this solubility is, in fact, a facility for breaking up into small particles. The short flaky fibres of fish-muscle separate and, therefore, dissolve more easily and quickly than the longer fibres of the flesh of oxen or sheep or poultry. Even in the different parts of the same animal there are differing degrees of digestibility, from the same purely physical cause. Thus the shorter fibres of the breast of a fowl render that part more suited to the need of a weak stomach than the leg, in which the muscle-fibres are longer. Next to the fish comes the joint, when the stomach has been prepared for the reception of the heavier part of the meal; and appropriately with the meat come vegetables, supplying inorganic salts, useful in the digestive process, and by their physico-chemical, as well as their nutrient, action, aiding the process of digestion. The bread and cheese, and dessert, play also useful tributary parts in the feeding as a whole. The bread gives dextrin, the cheese albuminoids, the dessert sweet fruity matters; all of which are useful. There is, however, a matter on which Dr. Brunton lays considerable stress, but which is, we believe, of even greater moment than he seems to ascribe to it; namely, the reflex stimulation of the nervous centres by the mechanical acts of mastication and swallowing, and the sensory excitation of the higher centres by the pleasures of taste in feeding. The Lettsomian lecturer gives greatly more prominence to this element in the function than previous expositors; but we incline to think it would be right to insist, even more strongly than he does, on the importance of "pleasantness" as a quality or property of the act of feeding. If a dinner be really enjoyed, it is seldom followed by indigestion. We are not now speaking of the brutish joy of the gourmand in filling his paunch to repletion, or of the fastidious delight of the gourmet in his gloating appetite for delicacies, but to the contented satisfaction of the rational diner, who finds the food to his taste and is stimulated "mentally" as well as "physically," that is, in his intellectual cerebral, as well as his animal sensory, centres, by the meal. Dr. Brunton estimates rather too highly, we think, the value and need of alcohol as an aid to digestion, for all except the very healthy of mankind. We have not space to pursue the subject further, nor is Dr. Brunton's admirable course of lectures sufficiently advanced in its publication to admit of a more detailed criticism. For the present, suffice it to say that we hail both the matter and the manner of the Lettsomian Lectures of this year as of very conspicuous merit and value to the profession, and, through its members, to the general community; and we venture to express a hope that the subject will engage the attention it deserves at the hands of all our readers. (British Medical fournal 1885;i:83.)

The Hong Kong Daily Press of November 15th, 1844, calls attention to the total want of provision for the Chinese wounded in the unfortunate contest that is being carried on in Formosa and Tonquin; and a correspondent from Tamsui, in Formosa, who has himself done much for the wounded at that place, assures us that, where the fighting has been lately going on, no preparation was made for treatment of the injured. Fortunately for the Chinese soldiers at Tamsui, there was medical help at hand, and we are informed by the Hong Kong newspaper that Dr. Browne, of H.M.S. Cockchafer, and Dr. Johansen, of Tamsui, saved a large number of soldiers from a painful death, while they greatly relieved the agony of others. It is terrible to think of the condition of the Chinese wounded who have been left untended and uncared for after the numerous battles that have been fought; and we are painfully surprised to learn that, whilst China has been spending money largely and freely on weapons and ammunition, she has spent nothing on provision for her wounded soldiers, who are sent on to meet the deadly artillery and rifle-fire of the French army. Surely this is a matter on which a little pressure might be brought to bear in the interests of a common humanity. The Chinese have taken their position amongst civilised nations; their envoys are received in every great European capital; and they claim the privileges of international law. Surely, then, civilisation has a right to expect that they will recognise it as a duty, not only to themselves, but to the nations into whose comity they have entered, to ensure that the horrors of war should not be needlessly increased. They have their trusted foreign advisers; and we hope that, through their means, this painful subject may be brought before the Chinese Government. The expenses connected with engaging a staff of foreign surgeons (the only help available now) would be a mere trifle, when compared with the outlay that the conduct of the war entails; but we would fain do the Chinese the justice of believing that they would not consider the cost, if the good that would result were pointed out to them. (British Medical fournal 1885;i:343.) 